\section{Influence of Sealing of the Screw Access Hole on the Fracture Resistance of Implant-Supported Restorations}

Rodrigo de Paula Pereira, Cibele Oliveira de Melo Rocha, José Maurício dos

Santos Nunes Reis, João Neudenir Arioli-Filho
Department of Dental Materials and Prosthodontics, Araraquara Dental School, UNESP Universidade Estadual Paulista, Araraquara, SP, Brazil

Correspondence: Dr. Rodrigo de Paula Pereira, Rua Humaitá, 1680, $4^{\circ}$ andar, 14801-903 Araraquara, SP, Brasil. Tel: +55-16-3301-6406. e-mail: dr.rodrigopereira@yahoo.com.br

\begin{abstract}
The purpose of this study was to assess the influence of sealing of the screw access hole (SAH) on the fracture resistance of metal-ceramic implant-supported restorations. UCLA abutments were used to make 30 implant-retained mandibular molar restorations and divide equally into three groups: Group SRS: screw-retained restorations with SAH sealed; Group SRNS: screw-retained restorations with SAH not sealed; Group CR: cement-retained restorations. The following protocol was adopted to restore the SAH: the ceramic surface of the SAH was air-abraded with aluminum oxide; etched with $10 \%$ hydrofluoric acid; a silane coupling agent and a bonding agent were applied; cotton pellets were used as filling material and $\mathrm{P}-60$ resin composite as restoring material. The cement-retained restorations were cemented with Rely-X U100. A metal rod with a spherical tip of $6.0 \mathrm{~mm}$ diameter was used to apply a vertical static load, simultaneously on the buccal and lingual incline cusps, at a crosshead speed of $0.5 \mathrm{~mm} / \mathrm{min}$ until the fracture of the specimens. Data were analyzed using one-way ANOVA and Dunnet test $(p<0.05)$ for multiples comparisons. The mode of failure was evaluated by a scanning electron microscopy (SEM). No significant difference between screw-retained restorations was found. The highest mean fracture resistance values were observed with $\mathrm{CR}$ group. Therefore, it was shown that SAH sealing did not influence the fracture resistance of the screw-retained restorations.
\end{abstract}

\author{
Key Words: fracture resistance, \\ screw access hole, screw- \\ retained implant-supported \\ restoration, cement-retained \\ implant-supported restoration.
}

\section{Introduction}

The use of metal-ceramics restorations is commonly in implant prosthodontics (1), maybe due to their mechanical strength (2). Nevertheless, the fracture of ceramic veneers is a problem that can occur $(1,3-5)$ and the longevity of ceramic veneers can be affected by the type of retention of the implant-supported restoration $(3,5,6)$.

Some papers showed that the screw-retained restorations have lower fracture resistance than cementretained restorations because the presence of the screw access hole (SAH) (1,3-9). The screw access hole represents a disruption of the porcelain continuity $(1,5-7,9)$ and a weak point of the ceramic layer (6), interfering with a natural occlusal morphology $(7,9)$ and influencing the fracture resistance of ceramic veneer (3).

The sealing the SAH with resin composite can be a solution to stabilize the occlusal surface of the screwretained restorations $(3,6)$. However, there are not uniform guidelines as to which material should be used to restore the screw access hole $(1,6,10)$. Consequently, in some studies $(1,3,6,10)$ that evaluated the fracture resistance of implant-supported restorations, the SAH was left unfilled just because that absence of guideline. Thus, future studies should be addressed to develop a protocol for filling the SAH to stabilize the ceramic veneer (6).
Therefore, the aim study was to verify if the sealing of the screw access hole influence the fracture resistance of the screw-retained implant-supported restoration.

\section{Material and Methods}

The specimens were divided equally into 3 groups $(n=10)$ : Group SRC: screw-retained restoration and restored screw access hole; Group SRNS: screw-retained restoration and unrestored screw access hole (negative control); Group CR: cement-retained restoration (positive control).

A metal matrix with an external hexagon implant analogue with a diameter of $5.0 \mathrm{~mm}$ (Biomet 3i, West Palm Beach, FL USA) and UCLA plastic cylinder were used to perform the metal ceramic crows (MC). The analogue was fixed inside the matrix with a lateral setscrew. UCLA plastic cylinders were bolted over the analogue and cut to allow that crows were waxed-up reproducing the dimension and anatomy of the mandibular molar with mesiodistal width of $11.0 \mathrm{~mm}$ and buccolingual width of $10.0 \mathrm{~mm}(1,4,10)$. With the purpose to standardize the final anatomy of the restorations and the thickness of the ceramic surface, two silicone (Zetalabor, Zhermack SPA, Rovigo, Italy) indexes (I1 and I2) of the waxed-up mandibular molar fixed inside metal matrix were made and sectioned in half from mesiodistal (I1) and from buccolingual (I2). 


\section{Preparation of the Specimens}

To make the specimens of groups SRS and SRNS, I1 and 12 were used to wax-up one mandibular molar, that was cut down simulating a metal framework to screwretained restoration on which is applied a ceramic layer around of $2 \mathrm{~mm}$ thickness including the screw access hole to improve esthetic results clinically (4). With the purpose to standardize the metal framework of all screw-retained restorations, two silicone (Zetalabor, Zhermack SPA, Rovigo, Italy) indexes (I3 and I4) of the waxed-up framework fixed inside metal matrix were made and sectioned in half from mesiodistal (I3) and from buccolingual (14), as was done with $\mathrm{I} 1$ and $\mathrm{I} 2$.

The waxed frameworks were cast in $\mathrm{Ni}-\mathrm{Cr}$ metal alloy (VeraBond II, AALBA Dent. Inc., Fairfield, CA, USA) according the standard casting and finishing recommended by manufacture's instruction and the marginal adaptation of the frameworks at the analogue was visually inspected with a sharp probe (Sonda \# 5, Golgran Ind. e Com. de Instrumental Odontológico LTDA., São Caetano do Sul, SP, Brazil). The, the ceramic (Noritake Super Porcelain EX-3; Noritake Kizai Co, Ltd, Nagoya, Japan) was applied according manufacture's recommendation and the presence of cracks in ceramic surface was analyzed under fluorescent light box and under a standard $4 x$ magnifying lens (1). The application of ceramic were made using 11 and 12 to standardize the final anatomy of the restorations and the thickness of the ceramic surface

To make the specimens of group CR, 13 and 14 indexes were used to wax-up a metal framework to screw-retained restoration and, afterward, were cut down simulating a abutment preparation with total taper around of $6^{\circ}(1,9,11)$ and $5.0 \mathrm{~mm}$ of height (1) regarding the adequate thickness to the metal copings and the ceramic surface. Another silicone (Zetalabor, Zhermack SPA, Rovigo, Italy) indexes (L5 and L6) were made and sectioned in half from mesiodistal for one and from buccolingual for other to standardize the framework of all abutments of the cement-retained restoration. Then, the waxed abutments were cast in $\mathrm{Ni}-\mathrm{Cr}$ metal alloy (VeraBond II, AALBA) according the standard casting and finishing recommended by manufacture's instruction. After casting and finishing, a thin layer with $0.5 \mathrm{~mm}$ of thickness of die spacer (4) was applied over abutments to allow room for the cement $(1,4)$, and the copings were waxed directly on the abutments keeping uniform thickness of $0.4 \mathrm{~mm}$ (1) and were also cast in $\mathrm{Ni}-\mathrm{Cr}$ metal alloy (VeraBond II, AALBA) according the standard casting and finishing recommended by manufacture's instruction.

Before veering of metal copings, the marginal adaptation of the abutments at the analogue and of the copings at the abutments were visually inspected with a sharp probe (Sonda Exploradora \# 5; Golgran Ind. e Com. de Instrumental Odontológico LTDA., São Caetano do Sul, SP, Brazil). Copings were veneered with ceramic (Noritake Super Porcelain EX-3; Noritake Kizai Co, Ltd, Nagoya, Japan) according manufacture's recommendation. $I 1$ and 12 indexes were used to standardize final anatomy and thickness of ceramic surface that was around of $2 \mathrm{~mm}$ (4), and the presence of cracks in ceramic surface was analyzed under fluorescent light box and under a standard $4 x$ magnifying lens (1).

Thirty external hexagon implants with a diameter of $5.0 \mathrm{~mm}$ and $10.0 \mathrm{~mm}$ length (Biomet 3i, West Palm Beach, $\mathrm{FL}$, USA) were embedded with Araldite GY1109 epoxy resin (Huntsman Química Brasil Ltda, São Paulo, SP, Brazil) $(3,6)$ in hollow implant holders and cured for $4 \mathrm{~h}$ at 70 ${ }^{\circ} \mathrm{C}$. Then, the specimen of groups SRS and SRNS and the abutments of group CR were connected at the implants and the occlusal screws were tightened using a torque device (Instrutherm TQ-680 - Instrutherm, São Paulo, SP, Brazil) to apply a torque of $32 \mathrm{~N} . \mathrm{cm}$ according manufacture's instruction. The screw was retightened after 5 min using the same torque device to prevent the screw loosening due compressive load (1).

In the specimens of group SRS, the screw access holes were sealed according the following protocol: ceramic surface of the SAH was air-abraded with aluminum oxide 50 $\mu \mathrm{m}$ (Bio-Art Equipamentos Odontológicos Ltda, São Carlos, SP, Brazil) at 35 psi for $20 \mathrm{~s}$; etched with hydrofluoric acid 10\% (Condicionador de Porcelanas, Dentsply Ind. e Com. Ltda, Petrópolis, RJ, Brazil) for 2 min and washed with water spray and dried. Hereafter, cotton pellets were condensed with an amalgam condenser (Condensador Ward \#2 Duflex; SSWhite Artigos Dentários LTDA, Rio de Janeiro, RJ, Brazil) and manual pressure up the interface metal-ceramic (3). A periodontal probe (Sonda Willians; Golgran) were used to standardize the amount of filling inside the channel and hence to limit the thickness of resin composite of sealing around $2.0 \mathrm{~mm}$. This standardization of the amount of filling materials and resin composite is important to comparison purposes (1) and, furthermore, the gray or black color of the SAH cited in the literature $(11,12)$ is avoided because the metal surface of the SAH is completely covered.

Following filling of the channel, a silane coupling agent (Silano, Dentsply) was applied on the ceramic surface of the SAH and, after $1 \mathrm{~min}$, a single coat of bonding agent (Scotchbond Multi Uso Plus; 3M ESPE, St Paul, MN, USA) was applied and polymerized for $20 \mathrm{~s}$ by a visible light unit (Curing Ligth XL3000; 3M ESPE) with a light-source intensity of at least $400 \mathrm{~mW} / \mathrm{cm}^{2}$. At the end, a resin composite (P60; $3 \mathrm{M}$ ESPE) was used to seal the SAH in 3 portions, each one being polymerized for $40 \mathrm{~s}$ by a visible light unit (Curing Ligth XL3000; 3M ESPE) with a light-source intensity of at 
least $400 \mathrm{~mW} / \mathrm{cm}^{2}$ at a distance of $10.0 \mathrm{~mm}$ from ceramic surface. The sealing of the SAH with resin composite was made with care to keep the occlusal anatomy of screwretained restoration. The SAHs in the specimens of the group SRNS were kept unfilled.

Cement-retained restorations of group CR had their inner surfaces and the surfaces of the abutments roughened with oxide aluminum $50 \mu \mathrm{m}$ at 2 bar pressure before cementation. The SAHs of the abutments were filled with cotton pellets (1) and, to cement the restorations, a resin cement (Rely X U100; 3M ESPE) was mixed following manufacture's recommendation. The restorations were seated on the abutments, the excess cement was removed with a probe (Sonda Exploradora \# 5; Golgran) and were kept in position under constant finger pressure around 5 min until the setting up of the cement.

Afterward the aforementioned procedures, all specimens were stored in distilled water for 7 days at $37^{\circ} \mathrm{C}$ and were following thermal cycled in a simulating machine of thermocycling (MSCT-3; Elquip, São Carlos, SP, Brazil) for $20 \mathrm{~h}$, what it means 1000 cycles, keeping $30 \mathrm{~s}$ at each temperature of $5{ }^{\circ} \mathrm{C}$ and $55{ }^{\circ} \mathrm{C}$ (2). The thermal cycling makes the results more clinically relevant because during this process can accumulate damage to the restorations (1).

\section{Fracture Resistance Testing}

The fracture resistance testing was performed in a universal testing machine (EMIC DL2000, São José dos Pinhais, PR, Brazil) with a $10 \mathrm{kN}$ vertical-compression load cell at $0.5 \mathrm{~mm} / \mathrm{min}$ cross-head speed (5) until the fracture of the specimens and the maximum load fracture at failure were recorded in N. The specimen was kept fixed inside a holding device by horizontal screws that allow horizontal movement of the specimen. A metal rod with a spherical tip with a diameter of $6.0 \mathrm{~mm}(1,4,10)$ was used to apply simultaneously load on the buccal and lingual cusp inclines of restoration simulating opposing occlusal contacts (5).

All data were analyzed using one-way ANOVA and Dunnett test for multiple comparisons, with a confidence interval of 95\% and a statistical significance was set at $p<0.05$. Statistical analyzes were performed using the computer program IBM SPSS Statistics version 20 (IBM Corporation, Armonk, NY, USA).

The mode of failure of the specimens was evaluated by a scanning electron microscope (SEM) (JSM - 6610LV; JEOL USA Inc., Peabody, MA, USA) and was classified as adhesive (failure at the ceramic-metal framework interface), cohesive (failure within the ceramic), or a combination (areas of cohesive and adhesive failure).

\section{Results}

The highest mean fracture resistance value occurred in group CR $(1489.28 \pm 569.30 \mathrm{~N})$, followed by group SRS $(825.66 \pm 250.36 \mathrm{~N})$ and group SRNS $(726.41 \pm 236.03 \mathrm{~N})$. One-way ANOVA identified a significant difference between the experimental groups ( $p=0.002)$. Dunnett test showed that the only significant difference was between group $C R$ and the other groups (Table 1).

\section{Mode of Failure}

All specimens were affected by a combination of failures (Figs. 1 and 2). In the specimens of Group SRS, besides the cohesive failure of ceramic and adhesive failure between ceramic-metal framework interface, it can be noted an adhesive failure between resin composite-ceramic interface (Figs. 3 and 4). In the specimens of Group CR, the detachment of the ceramic was lower than in the other groups, exposing only small parts of the metal framework (Fig. 5)

\section{Discussion}

The mechanical resistance of screw- or cement-retained implant-supported restorations should be considered to the long-term success of implant restorations (7). The screw access hole represents nearly 50 to $60 \%$ of occlusal table $(1,9,11,13)$, according the teeth $(9,11)$, what can weaken the occlusal ceramic surface $(1,4-6,9,10,13)$ and lead to more fractures of ceramic veneer in the screw-retained restorations $(1,4-6,10)$. In the study of Zarone et al. (7), was verified the presence of microcracks at the level of the SAH and extensive fractures in the whole thickness of the porcelain.

However, the adhesive restoration of the SAH could stabilize the ceramic veneer of implant-supported restorations $(3,6)$, despite there is no evidence-based to prove it (6). The effort needed to place an adhesive restoration in the SAH is greater than for other materials (3). In addition, there is not uniform guidelines of sealing of the SAH $(1,6,10)$. Thus, this study used a sealing protocol based in a repair procedure of fractures in metal-ceramics restorations described in the study of Santos et al (2), with the aim to stabilize the ceramic veneer (6).

The results of the present study showed no significant difference between sealed and not sealed screw-retained restorations, in other words, sealing of the SAH has not increased the fracture resistance of the screw-retained implant-supported restorations. These results indicate that the sealing of the SAH has not been able to stabilize the ceramic layer, as suggested in the literature $(3,6)$. However, is important to note that load was applied only on the ceramic surface avoiding contact of the spherical tip on the resin composite. Perchance, if the occlusal contacts had been distributed on or around the sealing resin composite, the results would have been different since size and location of occlusal contact areas affect the strength of dental 
ceramic (1).

In the study of Karl et al. (3), the screw-retained restorations with unrestored $\mathrm{SAH}$ showed significantly more chipping fractures than the screw-retained restoration with restored SAH. However, it is difficult to draw comparisons between the mentioned study and the present study because there are differences in the protocol of sealing of the SAH and in the mechanical testing used in both studies. In the study of Karl et al. (3), a dynamic loading was used and the number of cycles of load was limited to avoid complete

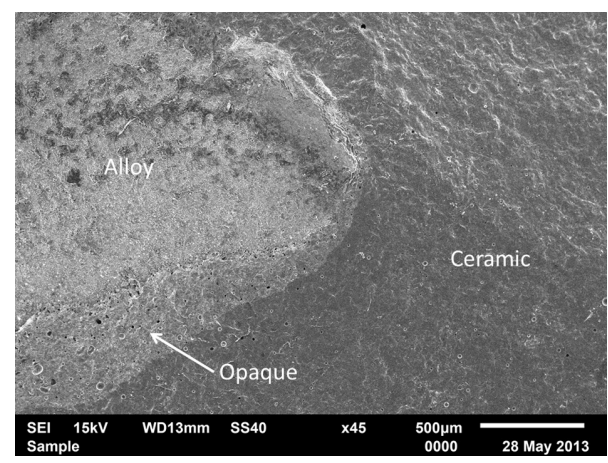

Figure 1. Combination of failures in a specimen of group CR.

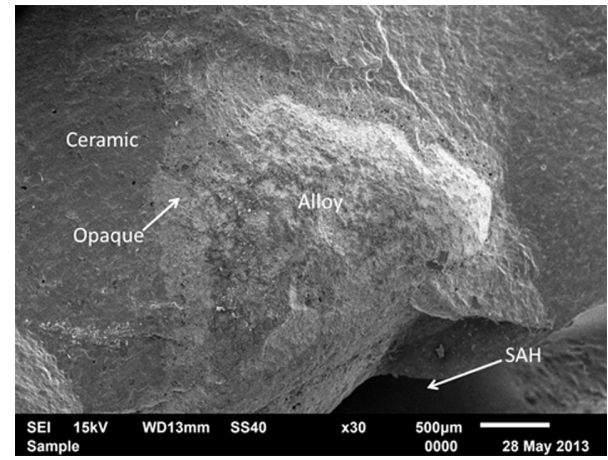

Figure 2. Combination of failures in a specimen of group SRNS.

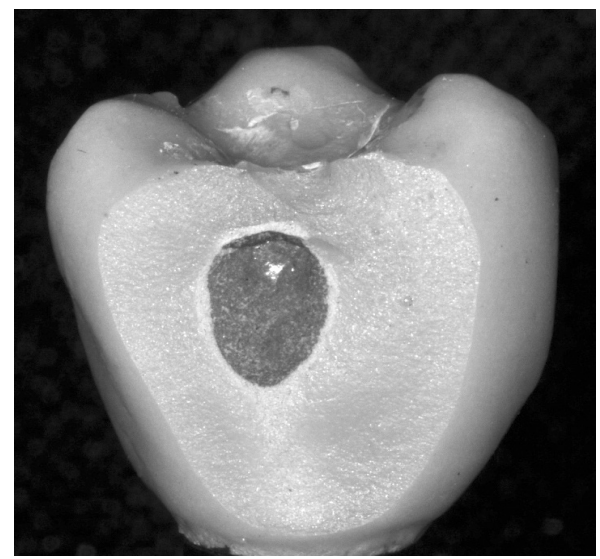

Figure 4. Fractured specimen of group SRS. fatigue of the specimens, which, according the authors, might have prevented the detection of differences. Thus, it is more difficult yet to draw comparisons since, in the present study an axial compression load was applied until the fracture of the specimens, what could have contributed to that there was no difference between screw-retained restorations with or without sealing of the $\mathrm{SAH}$.

More future researches are necessary to comparisons because the most studies in the literature use just experimental specimens with the SAH not sealed due the absence of uniform guidelines to seal it $(1,3,6,10)$. But, It is important emphasize that, clinically, the screw access hole must be sealed to keep the occlusal morphology, esthetic and function of the restoration.

Table 1. Mean load at fracture in Newton $(\mathrm{N})$ and Standard Deviation and results of Dunnett test

\begin{tabular}{lcc}
\hline \multicolumn{3}{c}{ Fracture resistance (N) } \\
\hline Group SRS & Group SRNS & Group CR \\
$825.66(250.36)$ B & $726.41(236.03)$ B & $1489.28(569.30)$ A \\
\hline
\end{tabular}

Different letters indicate statistically significant difference $(p<0.05)$.

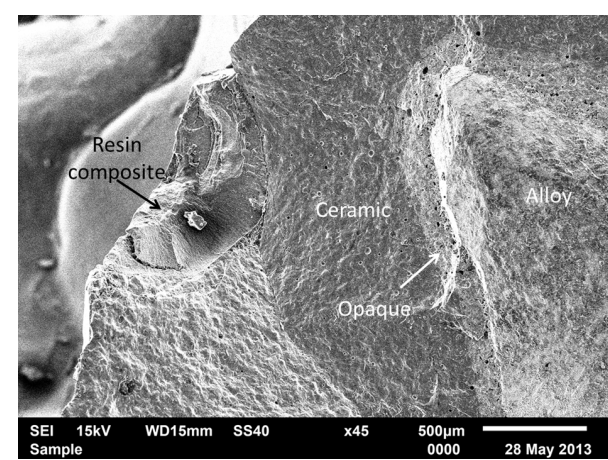

Figure 3. Combination of failures in a specimen of group SRS.

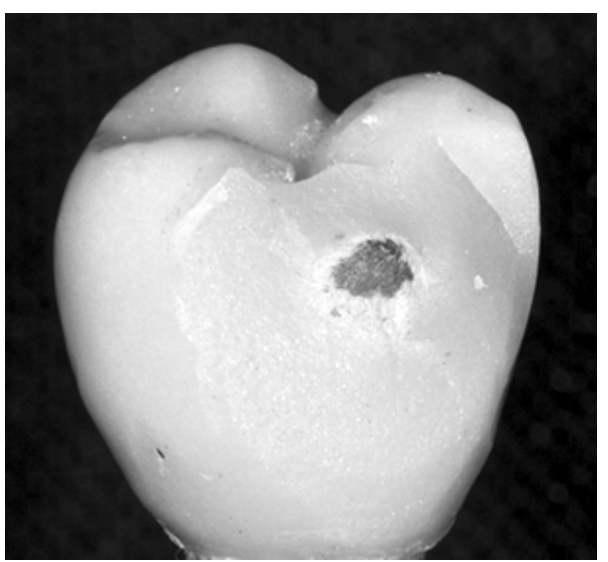

Figure 5. Fractured specimen of group CR. 
Regardless to seal or not the $\mathrm{SAH}$, the cement-retained restorations showed higher fracture resistance values, what is in accordance with other studies $(1,4,5)$. This finding can be explained by disruption in occlusal surface of the restoration caused by the SAH $(1,5-7,9)$, modifying the position of the center of mass of the ceramic bulk $(1,7)$ and leading to a weakness of the ceramic around the hole and at the cusp tips $(1,10)$. Therefore, maintenance the structural continuity of ceramic surface is determinative to a more fracture resistance of the cement-retained restorations.

All specimens had a combination of failures, but in the cement-retained restorations there were less detachments of ceramic. This is a result of the optimal effectiveness of the metal-ceramic bond in this type of restoration because it is not affected by geometrical variations of the metal framework $(1,7)$.

A limitation of the present study was the standardization of the experimental specimens. And one of factors associated with the fractures of dental ceramics is the shape and thickness of the ceramic veneer (1). Several technical steps were used to perform the restorations, such as silicone indexes, wax-ups, die spacer application and others steps that may be introduced variations of shape and thickness $\vec{s}$ of the ceramic veneer. In addition, cracks or flaws can exist within the ceramic layer since its fabrication relies on manual techniques (14). Due these factors, high standard deviation can be obtained $(1,14)$. Moreover, it was adopted a single load testing and, therefore, caution is needed to associate the present findings to a clinical situation due the cyclic nature of force intraorally (5).

However, even that fracture resistance of the screwretained implant restorations had been lower than cement-retained restorations, the values can be considered satisfactory for a good clinical performance because were higher than the average masticatory forces, that range between 20 and $830 \mathrm{~N}(14)$.

This study evaluated if the sealing of the SAH influences the fracture resistance of the metal-ceramic screw-retained implant-supported restorations. It was shown that the sealing of the SAH did not increase the fracture resistance of the screw-retained restorations. And the fracture resistance of the cement-retained restorations was higher than screw-retained restorations.

\section{Resumo}

0 objetivo deste estudo foi avaliar a influência do selamento do orifício de acesso ao parafuso (OAP) na resistência à fratura de coroas metalocerâmicas implantossuportadas aparafusadas. Pilares UCLA foram utilizados para fazer 30 molares inferiores implantossuportados e divididos igualmente em três grupos: Grupo AS: coroas aparafusadas com o OAP selado; Grupo ANS: coroas aparafusadas com o OAP não selado; Grupo CC: coroas cimentadas. 0 seguinte protocolo foi utilizado para selar o OAP: a superfície de cerâmica do OAP foi jateada com óxido de alumínio; condicionada com ácido fluoridrico a 10\%; um agente silano e um adesivo dentinário foram aplicados; bolinhas de algodão foram utilizadas como material de preenchimento e a resina composta P-60 como material de restauração. As coroas cimentadas foram cimentadas com Rely-X U100. Uma haste de metal com uma ponta esférica de $6.0 \mathrm{~mm}$ de diâmetro foi usada para aplicar uma carga estática vertical, simultaneamente nas vertentes triturantes das cúspides linguais e vestibulares, com 0,5 mm/ min velocidade do atuador até a fratura das coroas. Os dados foram analisados através de ANOVA um fator e teste de Dunnett $(p<0,05)$ para as comparações múltiplas. 0 modo de falha foi avaliado por um microscópio eletrônico de varredura (MEV). Não houve diferença significativa entre restaurações aparafusadas. Os maiores valores médios de resistência à fratura foram observados com o Grupo CC. Portanto, observou-se que o selamento do OAP não influenciou a resistência à fratura das coroas aparafusadas.

\section{References}

1. Al-Omari WM, Shadid R, Abu-Naba'a L and Masoud BE. Porcelain fracture resistance of screw-retained, cement-retained, and screwcement-retained implant-supported metal ceramic posterior crowns. J Prosthodont 2010;19:263-273.

2. Santos JG, Fonseca RG, Adabo GL, Cruz CAS. Shear bond strength of metal-ceramic repair systems. J Prosthet Dent 2006;96:165-173.

3. Karl M, Graef F, Wichmann MG and Heckmann SM. The effect of load cycling on metal ceramic screw-retained implant restorations with unrestored and restored screw access holes. J Prosthet Dent 2008;99:19-24.

4. Oliveira JLG, Martins LM, Sanada J, Oliveira PCG, Valle AL. The effect of framework design on fracture resistance of metal-ceramic implantsupported single crowns. Int J Prosthodont 2010;23:350-352.

5. Torrado E, Ercoli C, Mardini MA, Graser GN, Tallents RH, Cordaro L. A comparison of the porcelain fracture resistance of screw-retained and cement-retained implant-supported metal-ceramic crowns. J Prosthet Dent 2004;91:532-537.

6. Karl M, Graef F, Taylor TD and Heckmann SM. in vitro effect of load cycling on metal-ceramic cement- and screw-retained implant restorations. J Prosthet Dent 2007;97:137-40.

7. Zarone F, Sorrentino R, Traini T, lorio DD, Caputi S. Fracture resistance of implant-supported screw- versus cement-retained porcelain fused to metal single crowns: SEM fractographic analysis. Dent Mater 2007;23:296-301.

8. Park J-I, Yoon T-H. A three-dimensional image-superimposition CAD/ CAM technique to record the position and angulation of the implant abutment screw access channel. J Prosthet Dent 2013;109:57-60.

9. Hebel KS, Gajjar RC. Cement-retained versus screw-retained implant restorations: achieving optimal occlusion and esthetics in implant dentistry. J Prosthet Dent 1997;77:28-35.

10. Shadid RM, Abu-Naba'a L, Al-Omari WM, Asfar KR, Masoud BME. Effect of an occlusal screw-access hole on the fracture resistance of permanently cemented implant crowns: a laboratory study. Int J Prosthodont 2011;24:267-269.

11. Michalakis KX, Hirayama $H$, Garefis PD. Cement-retained versus screwretained implant restorations: a critical review. Int J Oral Maxillofac Implants 2003;18:719-728.

12. Kurt M, Ural Ç, Kulunk T, Sanal AF, Erkoçak A. The effect of screw color and technique to fill access hole on the final color of screw-retained implant crowns. J Oral Implantol 2011;36:673-679.

13. Vigolo P, Givani A, Majzoub Z, Cordioli G. Cemented versus screwretained implant-supported single-tooth crowns: a 4-year prospective clinical study. Int J Oral Maxillofac Implants 2004;19:260-265.

14. Ozcan M, Sleen JMvd, Kurunmaki H, Vallittu PK. Comparison of repair methods for ceramic-fused-to-metal crowns. J Prosthodont $2006 ; 15: 283-288$. 